\title{
Violence as a Subject of Social Science I The Specificity of Political Violence
}

\author{
Mario Domínguez Sánchez-Pinilla ${ }^{1}$, Isis Sánchez Estellés ${ }^{2}$ \\ ${ }^{1}$ Associated Professor at Faculty of Political Science and Sociology, University of Madrid, Spain \\ ${ }^{2}$ Researcher in Universidad de Valencia, Spain \\ maridomi@ucm.es
}

\begin{abstract}
In contrast to the world's uniformity all types of violence are observed: urban violence, in poor countries where conflicts are incomprehensible from outside, violence which surface is religious in countries of Muslim tradition, fundamentalist violence, nationalist, racist; violence in the world system which accepts the growing difference between poor and rich. Judiciary violence in executions in States that seem the principal warrantors of social peace. There is violence throughout the globe and under surveillance by the great power. It could be said that the global system tolerates a certain "reserve of violence" and obtains certain profits, as well as the economy tolerates certain extent of "unemployment rate" able to calm protest movements.
\end{abstract}

Keywords

political violence; typologies of violence; symbolic violence; terrorism

\section{Introduction}

\section{Towards an Unlikely Definition of Political Violence}

In this article we will approach the phenomena of political violence with an inclusive criterion, preventing moralizing criterion as a unique reference, we will observe different actors (individual and collective even States), and philosophical, psychological, and symbolic implications, inextricable part of the concept of violence.

First, a remark about political violence shows and advantage and a disadvantage. The advantage for the creation of this concept is a necessary and a healthy mixture of approaches. Indeed, a multidisciplinary topic, violence meets scientific aspirations: of combining sociological, political, historical, philosophical, and psychological even law perspectives. Regarding the disadvantage, the existence of multiple violence reflections and uniformity what is at stake is not only the difference between the intensity of the practices but also its purpose and nature. In addition, how to measure violence before mentioned is complicated. Though is odd to say, political violence is relative and its perception changes depending on time, social means, and cultural universes.

This shows how violence shall be quoted to exist, it could not exist as such, therefore is the result of a context a struggle of power. Furthermore, extreme violence, which expression is tough and equal comes from the logic of the concept. Violence cannot be objectified. 


\section{a. Violence: Subject Matter of Social Science}

Our first proposal consists of approach political violence to social reaction inside a particular social structure. As a start, an operative approach of political violence must be distinguished from others forms of action, those which have social connotations.

A usual definition of violence displays a constraint act, painfully experienced, since the phenomenon used strength or threats between individuals, groups, or institutions, to obtain something form individuals, which will not be conceded otherwise (Braud, 2004). For Tilly (1978: 176) violence is "every social interaction which as a result objects or people are damaged physically and intentionally, or those who are threatened with this infringement". This definition is extremely complete and at the same time incomplete. Extremely complete because opens the possibility to classified violence as any sort of pressure in opposition to self-willingness.

In contrast, this definition seems incomplete because its content approaches objectified violence only. In fact, violence is not just a restraint act: also, could be a tension; and its expression only made for satisfied anger, hate, or negative feelings.

The point is not to constrain, it is just to debased, destroyed, or built within the violent act. Violence always include victim and hangman, nonetheless, sometimes are not easy to distinguish. The constraining individual can be at the same time constrained, but it might forget this fact, thus he could become a hangman. Harm or fear are linked to violence but are not categories to define the concept. There are other elements complicating the definition, and in fact any definitions.

1) First, we shall point out that in each historical moment a fact linked to a concept can be defined in a different way compared to past times, and this does not suggest a universal thinking, since, in a particular time two different conceptions could coexist. This is the case of political violence, because not all the society recognizes the same things as violent, subsequently, there are those who would justify in different and even in oppositional ways certain things. This is not about individual violence, nor about the philosophical problems of violence in social relations, modern or ancient. Our consideration will approach political violence exclusively, collective conflicts in which the figure of the power and political decisions are present. The complexity of this issue can be remarked through paradigmatic statements in recent essays, with better intentions than preparation; where close definitions are given as if the explanation for violence and other realities located in the ins and outs of human's behavior individually and social, were possible through observation and common sense.

2) It seems clear, that what makes the difference between the types of violence is the proper object of the violence. In our case, what would make political violence a unique phenomenon is that the purpose is to modify, develop, sustain, or reproduce social order, and therefore relations and power structure that outline a society and the State. In conclusion if anything features any action of political violence that influences social order.

3) At last, violence in a historic perspective must consider a comparative study in terms of cross-national analysis. The historical analysis of social and political violence cannot extract convincing empiric bases if does not have a comparative projection using terms such as States, regions, territorial zones and politics clearly defined, a unique possible comparison in the subject matter of collective and individual violence.

The key matter which makes difficult to understand violence as a political fact, and for this reason easy to be an object for scientific sciences, as an expression of the human 
being where a temporary and intelligible development could be derived from the nature of violence as a general social element. In this concept there is not a clear perception, and it cannot be analyzed from the features of social facts.

To be able explain a general entity such as violence like a political-historical "phenomenon" it must be understood as a discriminated social fact. This particularization demands the starting point of violence as an internal relation inside any social structure. We do not know any historical society without presence of relations where the category of violence can be applied, what must be questioned is the extent and the frequency. We can only describe "violent phenomena" when certain individual and social actions have features that could reveal and allow unmistakable influences about social reproduction.

Albeit the characteristic of violence in contrast to other political actions is the use of force, as we can deduced from the definition afore mentioned. The usage of this mean to infringe willingness of those who promote a given social structure, in a way to subvert intentions and wishes. This will be done to achieve something that otherwise it will not be done.

Political violence in its different expressions consist always in an instrument of coactive power used to perpetuated, maintenance, modifications, or changes in the power itself, and therefore an element of order and social change. Is not unique, but in the human history can be traced its recurrent usage as means of support or modification of social order built in social relations, relations that are always power relations.

In this line, we can point out that political violence is a method to articulate the relation between rulers and governed, what displays its nature as a double phenomenon, it would be featured by its vertically and collectiveness. In contrast to this kind of violence, social nature could be distinguished for its horizontal character, because violently acts regarding willingness do not have power as an object; because it happens between actors at the same level, this means that can be individual and collective. Although the difference between political and social violence is not easy, as we showed. Every articulation process or social reproduction implies violence if we understand an "unlined resolution process of conflicts." Every process of this category has signs or remains of violence: the most primitive is a society, this unlined resolution is produced in a more generally way. Modern State regulates these rules, and the use of violence reserved in a monopolistic way, and it is since this moment where explicit regulation exists when we can characterize political violence as a specific phenomenon.

Before this division, political violence it does not seem a phenomenon that could be truly identified as "act", it rather seems a resource carefully normalized, with symbolic and ritual functions in favor or against power of social relations, etc. (Edelman, 1971) In the non-ontological vision of Michel Foucault (1977) he questions that he is trapped between violence and ideology, to end up with an image of manipulated power, self-conscious, repressive whose weapon is banning and its relationship with knowledge producing fake ideology.

The regulating notion is furthermore problematic, allows the observer before manipulation ideologically knowledge, the power is its place of creation. Presently, to be able to analyze political violence is necessary to craft a concept through the societies' consciousness of a structural function that can be modified and adjustable. "Etic" criterion is not possible but is necessary start on the "emic"; if a society is not conscious of violence as a social fact, it cannot be political history, unless we invented ourselves. That is what really happens in the truly historical evolution through social transformations, this trend tends to be more explicit, more visible, a specific phenomenon. On the other hand, the 
process of "visualization" violence is equivalent in its criminalization: a historic characterization of violent elements is generally compared at the same level with crime, in the visualization in terms of justice.

Criminalize violence is a slow historical process that allow us to speak about a "protocriminal" period. In the evolution of the mechanism of Justice, the violent act as an individual or collective product against the power. The struggle to control this power becomes a distinct component of some, it becomes considerable a powerful actor or against power. The struggle to control becomes structural. None of these cases show situations more explicit in contemporary capitalist societies, in which violence becomes a political reality and subsequently "historicable" as a category defined by phenomena. In other words, the proposal of recording a "history of political violence" generally, because it is not possible to determine clearly what shall be included or excluded in historic reconstruction of this sort. Every political analysis about violence must be developed in a determined expression of political violence. Plus, political violence has a truly intelligible sense when it comes to collective action. (Tilly, 1978; Della Porta, 2009).

\section{b. Characteristics for Differentiation}

There are three trends for differentiation or three perspectives for analysis that could be formed in the basis to study of the facts of political violence.

1) We should consider the essential approach introduced by the development of capitalist production in the presence of social and political violence. This is the first distinction between ancient or primitive violence where the "relation" is redundant, including the proper dynamic of social structures and new or modern violence as "act".

2) Violence expressed in the field of politics must be understood as a particular way of transcription or the most acute expression of a pivotal conflict of the society, the conflict between rulers and governed (Dahrendorf, 1974). This kind of conflict integrates other global conflicts such as class struggle when this conflict is solved or tries to be solved in the field of politics. A different nature of phenomena could be characterized as social violence, of a horizontal character, which appears on conflictive processes with or without explicit and arbitrary force. In which there are not power problems implied, notwithstanding unbalances of "social order".

3) A distinction focused on the temporary analysis of the process conflict-violence as the historic axis of movements and social changes, of the study of patterns and instrumentation in violence. However, it is common the misunderstanding of authors between the social process which leads to violence or violence as an expression; and the institutionalization of the concept used by one party to impose its position over the other party within the conflict. Patterns and instrumentation of violence are aspects to be analyzed in a separate way, in political violence as much as in social violence. In this sense, a remark could be made because of the misunderstanding introduced by analysts when they equal the concepts. Usually the often assimilation of "revolutions" or protest movements in less extent to simple violent situations. To most conservative authors, a "revolution" can be any type of subversive movement that achieves power and sometimes without achieving it. Any type of armed insurgency it is assimilated with terrorism and any social protest are qualified as insurgency. In a different perspective it does not make any sense considering as political violence what is displayed by these forms, which are possible to face imputation of the criminality individuals. It is only significant political violence or at least those violent situations which have achieved a level of interindividual participation, or a proper social level. 


\section{Review of Literature}

\section{Violence in Narrations of Social Life}

Political violence is in the center of great narrations of common life. Three philosophical perspectives always provide a core place. To the thinkers of the social contract, liberal or conservatives and the rejection of violence in the first place, something that triggers living together. The fear for disorder or the virtues of comer will replace the hostile nature where humans live. Violence is rooted in the social pact that searches stabilizing and pacifying social relations; therefore, any expression of war becomes impossible. On the contrary violence can be constructive, a positive variable of liberation oneself, the people: liberating violence. At last, from a neutral political perspective, without condemning or praising violence; violence is considered as part of humans. Psychoanalysis thesis considers violence is part of human action, an element and condition.

\section{a. Rejection to Violence}

The great narration against violence for the benefits of commerce, of tradition or of the social contract, they all agree in that society is based on an intellectual and practical rejection of a naturally destructive violence, it is an obstacle to progress and harmony. To Thomas Hobbes (Leviathan, 1651) the State is formed in the first place over the ashes of natural violence, in a way that the political link is based overall in voluntary rejection of war. The later stays permanently in a natural state, where "man is the wolf of man". There are three reasons that explain the anarchic state of nature: the endless desire to accumulate power, "a desire that only ends with dead"; the natural law overall that integrates the reality of a society without police or a code of property; Equality among men that makes precarious any domination by only one individual and unavoidable feeds the reinforcement of each one to maintain their own security. Rivalry, mistrust, and the search for profit and glory are the three causes of this natural violence that nothing can conduct except public power. This Leviathan-State is based on the will to make violence to violence.

Other authors of the social contract like Locke or Rousseau are contrary to Hobbes pessimistic idea of the natural state and his authoritarian conclusions regarding Leviathan's power. However, they are completely aware of the need to work for excluding violence, making men interested in the virtue of the republic (Rousseau) or promising the defense of their private interest. It is clear; in every thinker of the social contract there is a "Hobbesian trend" that becomes the foundation for policies against violence.

Violence is refused, not only by the State, but also by the logic market interest. Montesquieu (On the Spirit of the Laws, 1748) like Adam Smith (The Wealth of Nations, 1776) considered commercial exchange a way to overcome violence. Joseph Schumpeter (Capitalism, Socialism and Democracy, 1942) had the same point of view, who establishes a causality relationship between capitalism and pacification of costumes, sustaining that mercantile society and its rationality not only rejects violence and the useless financial cost of war, but also creates a "post heroic mentality", that places far away the war acts of the past. To Kant (Perpetual Peace, 1715) violence is contrary to democratic reasoning, according to which nobody will support a war that implies economic costs. And furthermore, allows transforming submission to other into submission to law. Traditional ideas of Edmund Burke (Reflections of the Revolution in France, 1790) were based on his rejection of violence, the excess of violence was a threat to social order funded on the respect for submission and transcendence of history. 


\section{b. Liberating Violence}

From the cult of virtuous terrorism imposed by Robespierre to the attempts to conceptualize decolonization, including the apology of war as a value on itself, violence has been for many thinkers full of qualities. Radical left wing from the sixties and seventies embraces violence, which had cathartic virtues and superior politics. The group that practices violence is morally reinforced, violence allows for social class cohesion, at the same time reveals the real conflicts that exist among different social classes. This revelation takes places within the proletariat that becomes aware by action, of his strength and unity. Also, the adversarial, the bourgeoisie is compelled to show his "real face" that of a "police dictatorship" simulated under a fake democracy. For some Marxists authors planned violence, not spontaneous, is a necessary means to achieve the new world liberated from capitalist exploitation and take the power over the State (it is always the objective). Even violence appears as a psychological need, as Frantz Fanon and Jean Paul Sartre sustained and wanted to show the ways of liberations to working or colonized people. The author of The wretched of the earth (1961) holds that violence means liberation for those colonized, that they become a man by the mere fact of killing. Slavoj Zizek (2008) is often close to these ideas, he makes Saint Just premises his: What produces the general well-being is always terrible". Terror is understood as humanism, real expression of the voice of the people.

This cathartic function is also present in the other political extreme, in fascist thought or in Georges Sorel (1999) that for a time was close to it. To the author of Reflections on violence social revolution is not a program but a practice that must exercise the worker. Only everyday conflicts, the confrontation with employers can open a new era. Sorel had an influenced on young Mussolini, he learned from him the cult to violence and passion, against rationality and against democratic compromise. Also, in this case, fascism is more than just an historical period: it is a rejection to ideas, praising of violence and war, that sublimates human action, and it reveals the power of people against the cowards and expired elites.

\section{c. Unavoidable Violence}

To psychoanalysis thinking violence is proper of humans; violence is part of the response to confrontation between the principle of desire and the principle of reality. Freud talks comments there is a pronounced tension concerning death in all people, which urges people to self- destruction. To avoid this trend, violence is not conducted to oneself, is addressed to the outside, serving sexual functions. To H. Laborit or K. Lorenz, animal aggression instinct can be found in humans, related to competitive aggressiveness (defending a territory, for example) (Laborit, 1970), therefore not just in predatory aggressiveness (attacks) or defensive (when escaping is a possibility). Violence will be an endogenous feature of human behavior, remarking human belonging to animal world.

\section{Results and Discussion}

\section{Typologies of Violence}

It must be pointed out that there are two great oppositions that go beyond any forms of expressing political violence and its intensity, one that divides the physical violence from the symbolic one, and the other the one that divides political violence from social one. We will see that this division is very fragile, and in fact such typologies are observable dimensions of political violence. 


\section{a. Symbolic Violence and Physical Violence}

Michel Foucault (1977) was remarkable pointing out about the appearance of violent mechanisms that depend on the humanist premises of the period that he situated by the end of XVIII century, those ideas allow a harder repression but less cruel. The expression of power is transformed: from visible and cruel punishment to establish mechanisms of surveillance and control of bodies and souls. In practice, it means modern prisons and all social institutions create a scientific knowledge to serve the State: hospitals, asylums, psychiatric institutions, schools, etc. "Punishment became from being an art of unbearable physical sensations to an economy of suspended rights" (Foucault, 1977).

Other authors extend this idea of Foucault, stressing the expanding of symbolic violence, rather than physical one in the modern world, that oblige to question the thesis of a pacification of our society. The Norwegian political scientist Johan Galtung (1996) establishes a difference between "negative peace" (absence of war) and "positive peace" (the end of structural violence), and then he proposes an extensive definition of violence that goes beyond "direct violence" such as aggression and beating? This author understands structural violence as a systematic action of the social structures or an institution that does not allow people to satisfy their basic needs. Structural violence of frustrated individual and collective expectations is an invisible phenomenon that favors, especially when it is culturally legitimated, the expression of direct violence, particularly visible forms.

The concept of symbolic violence became an analytic concept with Pierre Bourdieu (1977) it was one of his main lines of his sociological thought. According to him, symbolic violence works as a double mechanism of recognizing and unknowing. The domination of a few is only possible because the dominated recognize the establishment /or the social order established, at the same time, the dominated do not know the arbitrary character of the establishment and the alienation that implies. For Bourdieu that mechanism of "voluntary servitude" that remain us Étienne de la Boétie (Discourse on Voluntary Servitude, 1548) is scary, because violence, invisible for those who are submitted to it, it appears completely interiorized in the habitus of everyone (inner mental structures that comes from social class socialization).

Bourdieu holds that the State, the institutions, and the practices of the establishment (school, university, mass media, political language) are places or expressions of symbolic violence that tend to hide, under a naturalist appearance, submission relationships, at the same time these invisible relationships have terrible social consequences. Sociologists work according to Bourdieu is to contribute to unveil for dominators and dominated the simulated reality of those mechanisms of violence. Thus, the notion of symbolic violence constitutes a strong critic to the establishment.

On the other hand, his success resides in part in his radical approach to research, providing in every field of social science "evidence" of the domination experienced by those who were interested in the impugnation of hierarchies. However, this notion is politically useful but sometimes is not convincing. In the first place, there is a problem of internal logic in the model. If symbolic violence is based on the ignorance of experiencing suffering, it seems difficult to change these circumstances till the actors (the victims) become aware of the violence that is exercised on them.

Why, forced, assaulted submitted actors should react to violence that they do not feel at all? This will mean to pretend that only sociologists can promote and awareness of the dominated, if that is the case, some could think that intellectuals are more than anything else an organizer of presumed and invisible types of violence, and that only them can 
uncover. Furthermore, by defining the State as a "monopoly of legitimated symbolic violence"; Bourdieu tends to mix up legality with legitimacy, forgetting that at least in democracy, the State defines what it is legal and society what is legitimate. The strongest critic that can be done to this notion is still the disconnection between violence and suffering, as well as the lack of arguments (explanation) regarding the relationship that exists between symbolic and physical violence.

Philippe Braud (2004) differentiates between two types of symbolic violence and remarks its painful effects. The first one is "devaluated identity", the assault to a personal o group identity that is deeply consolidated. This kind of violence has a symbolic dimension that it hurts. Thus, expressions such as heterophobia (disdain towards a racial or sexual identity different to one's own), superiority discourse (colonial discourse) or the negation of suffering (that can be found in negativist arguments).

The second one is "instability of referential points of view" that is the deliberated attack on beliefs, norms and values that give meaning to the individual's world view. The offence towards the history o memory of a group, the confrontation of antagonistic references (occidental materialism in Muslim land) or the maladjustment of references that question well and long-established beliefs (for instance in communist idealism) They are the kind of symbolic violence, that surely can be found in the roots of physical conflicts.

Physical violence, on the contrary, seems much easier to define. It is directly linked to the exercise of aggression, and it is based on the fact of experimenting pain. However even though the definition seems simple, the plurality of so many ways of expressing physical violence makes it rather difficult to approach such a concept. We distinguish three ways to understand this kind of violence.

The first one is equivalent to consider violence as contingent to the social order, (Eckstein, 2002), an expression that becomes necessary by a dysfunction of society. Thus, it could be passionate violence to manifest collective or individual momentary anger, or frustration. These forms of violence are the most visible and frighten because they appear to be irrational, extreme, and sudden. The archetypical form of this violence is unwarranted violence, with no other reason than just the pleasure of the act of violence. This violence is very important, specially, since it is a respond to an objective frustration, and can have mechanisms of cultural justifications.

The second way to consider violence is as inherent to the political action and system, a form of collective expression as others, that responds to a logic of calculating, of strategy, and not only to a passionate impulse. "Instrumental violence" is proportional to the objective that wants to attain, always paying attention to efficacy and success. It is of course the violence exercised by the State, to perpetuate the social order, for example when the supposed objective it is not to kill the enemy but rather "to persuade the citizen to be a lawful person" using police lexicon. It is also the violence used by certain protest groups (trade unions, social movements), they show an extremism often pretended in order to be heard, but without ever taking the risk to use blind violence that could put their prestige into question.

At last, the third way to read physical violence is linked to the identity dimension, violence is not only considered as an expression of anger or an unconventional way of political expression, rather it is the means to validate collective identity of those who practice it, or the other way round, a way to deny the identity of those who experience the violence. There are many examples of a hieratic use of violence, for the purposes of the ambition and pretentiousness of the fighters. Violence makes a tribe, builds up the tribal identity, whether is young delinquent bands, Irish paramilitary, Corsican, or riots squads in 
activity. It crafts a fighter and virile identity, aimed at reinforcing the group cohesion, its homogeneity, to rise what is put on scene: a band, a village, a State. Eric Desmons (2005) points out the function of incarnation that insurrection barricade has: according to Blanqui the people exercise "a powerful act of sovereignty", using violence to make the nation exist. Oppositely, violence can also be used to deny the identity that victims claim o may deserve. It is, of course, the violence of concentration camps, they not only wanted to kill all Jews in Europe, but also to show that they were subhuman, trying to deprive them from humanity. We can see the identity dimension of violence in both cases.

\section{b. Political Violence and Social Violence}

To define violence as political or social appears to be relatively simple, as we mentioned before. For example, gender violence, bullying, and conflicts that have an unlined resolution, that they do not show an unbalance to be sorted out on the political field, they do not seem to belong to the category political violence. As opposite, terrorist attack of Hamas, even though its meaning is not always clear, belong to this category. The difference between political and social violence, is the object of violence, the status of actors involved, their discourse and its effects.

However, many elements contribute to make this difference rather vague: even some speak of a real "blurred limit" (Sommier, 1998, 2000, 2008). What weakens the opposition between "these two types of violence" is in the first place the moral bias. To describe the very act as a political one means to give it a rather distinguished justification, always an acceptable explanation. Violence tries to be heard, even when deep motivations are different to the explicit intentions.

As opposite, to demand criminality of other, his exclusive desire to enrichment, his unwarranted sadism, means to deny all the political dimension to attribute to that act a mere evil interest. To decide which act of violence is a political one and which is not influence on the process of legitimacy of a practice morally condemnatory. The cases of suburban riots are an example of this. For some authors, the riots represent a political action inscribed in the tradition of rebellion against the power and manifest the collective will to be listened by a distant State (Crettiez \& Mucchielli, 2010). For others, the target of violence (cars, schools, and business) shows an ambitious deprivation from the violent, far away from any political claim. As it can be seen, there are different interpretations underlying the analysis that have important performative effects. In turn political violence just by the fact of acting in the political field, exercised by actors that pretend to be political and have political effects can unveil itself far away from this category.

However, the discovery of the logic of violence has showed that behind political aspects there were strictly material and financial motivations that were very remote from the ideological discourses (Crettiez, 2008). Thus, regarding the definition of political violence, it all depends on the adopted criterion. We can find a more tangible explanation by considering the ideology and objectives of violence rather than considering the possible effects on the political sphere. Thus, gender violence present in the mass media and could lead to a bill of protecting women from violence, then this case could be classified as political.

Charles Tilly (1978) also showed the fragility of this division. Collective violence that he analyzed for a long period in Europe (from XVI to XX century) is at the same time political and social (Tilly, 2003). The primitive collective violence resides on a communitarian base and uses common moments of socialization; it appears often as attempting to question the power. The same happens with the reactionary collective 
violence, usually appears as a reaction to submission to taxes or very expensive prices on food. At last, the modern collective violence, more autonomous and with and associative base, it responds directly to the category of political, since relies in trade unions activism. It is objective is to obtain or defend the rights given by the authorities (Tilly, 1978). In all cases, the use of violence and its form depends on the relationship with the State (or with the legitimated authority) who can transform the social violence on a repertory of political actions.

To Michael Wieviorka (2009) political violence is classified according to their relationship with the public sphere and for that very reason is in permanent interchange with social violence. "The meanings attached yesterday to violence linked in a political level... today may be far from it, on one hand privatizing, taking certain distance from the public sphere- is the infrapolitical violence- and on the other hand, given the action religious dimensions, that subordinate political affairs to a superior principle, the sacred is the metapolitical violence." Political violence evolution needs a wider frame, not only in the center of politics but also in its borders. An example would be Marxist guerrilla transformed in prosperous narcos or Al Qaeda terrorism, with their extremist messages and acts becomes opposite to any political concessions. Changes that have taken place in violence made the question of its social or political roots very complex.

\section{Conclusion}

Likewise, all social phenomena are a result of a clash of definitions between actors with differing interests and resources: a terrible struggle, above all, because of the accusatory and morally reprehensible conception developed in a pacific world. In this world violent individuals usually do not have reason. A proof of the complexity of the subject matter is due to the usual concept of violence.

Presently, violence is an empty signifier because it has not got an over determined meaning, without the relation between signifier and meaning are totally contingent. That is why democratic States are not conventionally "violent", and they rather refer to the "legitimate force" meanwhile classifies as violent, opposition demonstrators. However not everyone is empowered to classified and quote concepts. In this scope, visible violence is always on the adversary side, coactions and constraint are a capacity of those who are in favor of order.

This asymmetry leads political violence to be a subject matter judge as negative common concept. However, most modern political entities are not made up by a voluntary aggregation: a high number of democratic advances or social conquests have been achieved by mass violence, disturbs, even insurrections and civil wars.

\section{References}

Bourdieu, Pierre (1977). Outline of a Theory of Practice. Cambridge, University Press. Braud, Philippe (2004). Violences politiques. Paris, Editions du Seuil.

Crettiez, Xavier (2008). Les formes de la violence. Paris, La Découverte.

Crettiez, Xavier \& Mucchielli, Laurent (dir.) (2010). Les violences politiques en Europe: Un état des lieux. Paris, La Découverte.

Dahrendorf, Ralf (1974). "Towards a theory of social conflict" in E. \& A. Etzioni (eds.). Social Change: Sources, Patterns, and Consequences. New York, Basic Books. 
Della Porta, Donatella (ed.) (2009). Democracy in Social Movements. Basingstoke, Hampshire, Palgrave Macmillan.

Desmons, Éric (2005). "Philosophie sur la barricade", in Dominique GROS, Le droit de résistance à l'oppression. Paris, Seuil.

Edelman, Murray (1971). Politics as a Symbolic Action. Chicago, Markham.

Elias, Norbert (1969-1982). The Civilizing Process, Vol. I. The History of Manners, Vol. II. State Formation and Civilization. Oxford, Blackwell.

Foucault, Michel (1977). Discipline and Punish: The Birth of the Prison. New York, Vintage books.

Galtung, Johan (1996). Peace by Peaceful Means: Peace and Conflict, Development and Civilization. London, SAGE.

Girard, René (1977). Violence and the Sacred. Baltimore, Johns Hopkins University Press [orig. 1972].

Laborit, Henri (1970). L'agressivité étorunée. Paris, Union Générale d'Editions.

Rizal, Muhammad \& Djannah, Fathul (2020). Impact of Violence against Children in the Family. BIRCI-Journal, Volume3, N.1, February 2020, 348-358. https://doi.org/10.33258/birci.v3i1.746

Romeu, Vivian (2020). Notes for a Critique to the Program of the Sociology of Emotions. Konfrontasi, 7(1), 67-76. https://doi.org/10.33258/konfrontasi2.v7i1.98

Sommier, Isabelle (1998). La violence politique et son deuil: L'âpres 68 en France et en Italie. Rennes, Presses Universitaires.

Sommier, Isabelle (2000). Le terrorisme. Paris, Flammarion.

Sommier, Isabelle (2008). La violence révolutionnaire. Paris, Presses de SciencesPo.

Sorel, Georges (1999). Reflections on Violence. Cambridge, Cambridge University Press [orig.1908].

Tilly, Charles (1978). From Mobilization to Revolution. Canada, Longman Higher Education.

Tilly, Charles (2003). The Politics of Collective Violence. Cambridge, Cambridge University Press.

Wieviorka, Michel (2009). Violence: A New Approach. London, SAGE.

Zizek, Slavoj (2008). In Defense of Lost Causes. London, Verso. 